"Volume 15, No. 2, Desember 2021"

\title{
KONSEPSI DAN INTERNALISASI NILAI POWER AND AUTHORITY DALAM PENDIDIKAN PESANTREN
}

\author{
Oleh: \\ Badrut Tamam \& Hariyanto \\ UIN Sultan Aji Muhammad Idris Samarinda \\ Universitas Ibrahimy Sukorejo Situbondo \\ badruttamam@iain-samarinda.ac.id \& hariyantolppm@gmail.com
}

\begin{abstract}
:
This article elaborates the conception and internalization of the value of power and authority in the context of education in Islamic boarding schools. Power is a mandate opportunity for individuals or groups of people to awaken other individuals or groups to accept the will they want either by coercion or the legitimacy of awareness from other individuals. Authority or authority is the right to do something or instruct others to do or not do something with the aim that the mission of the institution is achieved properly. This study uses a qualitative research approach and uses data collection techniques in the form of observation, interviews and documentation. The types or sources of power and authority used by the kiai of Pondok Pesantren Miftahul Ulum are referent power, reward power, coercive power, legitimate power and expert power. The five types and sources of power and authority serve as reinforcement in the managerial role of a kiai and for the development of Islamic boarding schools.
\end{abstract}

Keywords: Power, Authority, Pendidikan, Pesantren

\section{A. Pendahuluan}

Manusia dilahirkan untuk hidup yang tidak berdaya, dan Tuhan telah memberi mereka berbagai potensi. Pendidikan bertanggung jawab untuk pengembangan dan realisasi semua potensi manusia. Melalui pendidikan manusia, manusia berharap dapat terus berkembang dan berubah, sehingga disadari atau tidak disadari bahwa pendidikan memegang peranan yang sangat penting dalam kehidupan manusia.

Dalam proses pendidikan, dengan terus berkembangnya berbagai kekuatan pendorong, terdapat kekuatan yang mendorong tuntutan masyarakat untuk meningkatkan taraf hidup atau menjadi eskalator sosial. Oleh karena itu, tidak jarang kekuasaan merambah proses pendidikan dalam berbagai bentuk. Kekuatan ini dapat diwujudkan secara obyektif atau publik, subyektif atau tidak disadari, atau disebut kurikulum 
tersembunyi dalam bentuk ekspresi kurikulum.

Memang, jika kita melihat pada dua konsep kekuasaan dan pendidikan, keduanya akan memiliki arti dan penelitian yang berbeda. Di suatu negara, kekuasaan sama dengan politik dan pemerintahan, dan pendidikan sama dengan proses belajar atau transfer ilmu. Namun, jika kita melihat lebih dalam dan lebih luas, akan ada banyak hubungan (kekuasaan dan pendidikan) di antara keduanya. Artinya ketika ternyata keduanya memiliki hubungan yang sangat erat dan saling mempengaruhi, bukan tidak mungkin.

Berbicara tentang kekuasaan berarti kita berbicara tentang kelompok atau orang yang mengontrol atau dikendalikan. Kemudian berbicara tentang proses pendidikan, ada orang atau sekelompok pendidik dan orang atau sekelompok siswa. Kita dapat mengasumsikan bahwa kekuasaan dan pendidikan memiliki peran dan hubungan yang sangat strategis dalam praktiknya, dan keduanya melibatkan dua orang atau kelompok. Keduanya memiliki tujuan yang berbeda, tetapi keduanya dapat menembus dan mempengaruhi kepentingan yang berbeda.

Persoalan antara kekuasaan, otoritas dan pendidikan masih saja unik untuk dikaji secara mendalam, karena pendidikan akan selalu berada dalam lingkaran perebutan kekuasaan sosial. Akibatnya, perebutan kekuasaan bisa berdampak negatif dan positif dalam pendidikan. Jika pendidikan digunakan sebagai alat untuk mempertahankan kekuatan kelompok maka akan berdampak negatif, jika pendidikan diintegrasikan ke dalam kehidupan masyarakat maka akan berdampak positif. Kedua pengaruh ini juga berlaku untuk proses pembelajaran pendidikan.

Sejarah pendidikan di Indonesia mencatat dengan jelas bahwa lembaga pendidikan tertua di negeri ini merupakan pondok pesantren. Para ahli dan praktisi pendidikan sepakat bahwa pondok pesantren dengan kekhasan serta dinamika yang bergulir sepanjang sejarah merupakan warisan penting yang harus dijaga kelestariannya.

Pondok Pesantren merupakan lembaga pendidikan yang memiliki corak islami disamping corak asli Indonesia. Selain itu, sebagai lembaga pendidikan Islam, Dengan perkembangan maka bentuk perkembangan zaman terutama pengaruh kemajuan ilmu pengetahuan dan teknologi. Perubahan petani tidak ada artinya sebagai tempat pendidikan yang telah kehilangan ciri khasnya. dalam keadaan ini pondok pesantren masih merupakan institusi pendidikan Islam yang sedang berkembang tumbuh dari satu masyarakat ke masyarakat lainnya. Sejarahnya, pondok pesantren merupakan fondasi utama yang perkembangannya sejalan 
dengan pola perkembangan masyarakat.

Berdasarkan latar belakang di atas, maka kami mencoba menjelaskan penggunaan kekuasaan dalam pembahasan rinci tentang manajemen kekuasaan: pengertian kekuasaan, sumber dan bentuk kekuasaan, ciri-ciri kekuasaan, dan hubungan antara kekuasaan dan pendidikan. Adapun tujuan penulisan artikel ini untuk mengetahui bagaimana konsepsi dan internalisasi nilai power and authority dalam pendidikan pesantren (studi pada pesantren Miftahul Ulum Kalisat Jember) sedang metode penelitian dilakukan dengan metode penelitian kualitatif dan menggunakan teknik pengumpulan data berupa observasi, wawancara dan dokumentasi.

\section{B. Pembahasan}

\section{Konsepsi Power and Authority dalam Pendidikan Pesantren}

Konsep power atau kekuasaan sangat erat kaitannya dengan konsep kepemimpinan. Dengan memiliki kekuasaan, pemimpin dapat memperoleh alat untuk mempengaruhi perilaku pengikutnya. Pemimpin tidak hanya harus mengevaluasi perilaku mereka sendiri sehingga mereka dapat memahami bagaimana mereka mempengaruhi orang lain, tetapi pemimpin juga harus bersedia dan mampu mengevaluasi posisi mereka dan bagaimana menggunakan kekuasaan.

Pelopor paling awal yang menggunakan istilah kekuasaan adalah sosiolog terkenal Max Waber, yang mendefinisikan kekuasaan sebagai kemungkinan untuk memungkinkan para aktor dalam hubungan sosial mewujudkan keinginan mereka1. Griffin dan Moorhead ${ }^{2}$ mendefinisikan kekuatan sebagai kemampuan potensial seseorang atau kelompok untuk menjalankan kendali atas orang lain atau kelompok (Kekuasaan adalah kemampuan potensial seseorang atau kelompok untuk menjalankan kendali atas orang atau kelompok lain.

Menurut Garry Yukl ${ }^{3}$, Konsep kekuasaan sangat penting untuk memahami bagaimana orang saling mempengaruhi dalam suatu organisasi.Kekuasaan melibatkan kemampuan satu pihak (agen) untuk mempengaruhi pihak lain (sasaran). Selain itu, Paul Hersey, Kenneth H.

\footnotetext{
${ }^{1}$ M Chairul Basrun Umanailo, MAX WEBER (Namlea: FAM PUBLISHING, 2019), 29, https://doi.org/10.31219/osf.io/ep7bn.

2 Ricky W. Griffin dan Gregory Moorhead, “Organizational Behavior ," (Boston, Massachusetts, Amerika: Cengage Learning, 2011), 21.

3 Gary A. Yukl, Leadership in Organizations (Upper Saddle River, New Jersey, Amerika: Prentice Hall, 1998), 31.
} 
Blanchard, dan Dewey E. Johnson ${ }^{4}$ mendefinisikan kekuasaan. 'We earlier defined leadership as an attempt to influence another individual or group and concludedthat leadership is an influence process. Power is influence potential the resource that enables a leader to again compliance or commitment from other'(Kekuasaan berhubungan dengan kepemimpinan, dan kepemimpinan adalah usaha menggunakan kekuasaan untuk mempengaruhi orang lain. Penggunaan kekuasaan selalu menghasilkan perubahan pada kemungkinan-kemungkinan yang dimiliki seseorang maupun kelompok dalam menciptakan perubahan perilaku yang diharapkan sehingga kekuasaan merupakan key konsep dari seorang pemimpin.

Pondok Pesantren memang merupakan lembaga pendidikan Islam tradisional, namun dalam perkembangannya menyelenggarakan sistem pendidikan formal. Nilai dan norma pesantren yang dulunya penting kini hanya ditambahkan sebagai nilai tambah lembaga pendidikan formal yang sudah mapan. Perubahan ini terjadi terutama setelah Belanda memperkenalkan sistem pendidikan Barat pada abad ke 19. Menurut Zamakhsyari Dhofir, sistem pendidikan melahirkan lulusan yang kemudian menjadi kelompok terpelajar yang dapat menggantikan kiai sebagai intelektual dan komunitas kepemimpinan.

Menurut Pasal 9 ayat 2 Bab 3, Undang-Undang Nomor 18 Tahun 2019 tentang Pondok Pesantren menetapkan bahwa Kiai sebagaimana dimaksud pada ayat (1) adalah pimpinan tertinggi pesantren, dan dapat menjadi pengurus pesantren. Menjabat sebagai pengurus, karakter dan panutan. Dilihat dari peran dan fungsinya, orang Kiai adalah pemimpin pesantren, yang dapat dikatakan sebagai fenomena kepemimpinan yang unik, karena selain memimpin lembaga pendidikan Islam, mereka tidak hanya bertanggung jawab menyusun kurikulum, membuat aturan, merancang sistem evaluasi, dan Melaksanakan proses belajar mengajar yang berkaitan dengan ilmu agama, dibawah asuhannya ia juga bertindak sebagai pembina, pendidik dan tokoh masyarakat.

Kondisi tersebut menuntut Kiai memiliki kearifan dan ilmu dalam peran dan fungsinya, mahir dalam ilmu agama, mampu menanamkan sikap dan pendapat, serta menjadi teladan pemimpin (panutan) agar menjadi pemimpin yang baik, dan Kiai di kalangan pesantren. Terkait dengan kekuatan supernatural. Mereka yang dianggap ulama adalah ahli

4 Paul Hersey, Kenneth H. Blanchard, dan Dewey E. Johnson, Management of Organizational Behavior: Leading Human Resources, 11 ed. (London ; Britania Raya: Pearson, 2013), 36.

$184 \mid$ JURNAL LISAN AL-HAL 
waris kitab-kitab kenabian, sehingga keberadaannya dianggap memiliki hubungan yang erat dengan Tuhan.

Gaya kepemimpinan Kiai berikut karakteristiknya dan peran penting dalam menjadikan pesantren sebagai lembaga pendidikan komprehensif yang terus eksis dengan perkembangan teknologi, membekali santri dengan kecakapan hidup, serta membangun relasi dengan lembaga dan komunitas lain.

Dalam hal ini, Kiai adalah tokoh sentral dalam pembinaan di kalangan pesantren. Komunitas ini diperuntukkan bagi mereka yang memiliki pemahaman mendalam tentang Islam, memiliki dan memimpin pesantren, serta mengajarkan buku-buku klasik kepada santri.

Menurut Zamakhsari Dhoefir ${ }^{5}$ menunjukkan bahwa sebagian besar masyarakat beranggapan bahwa pesantren merupakan kerajaan kecil dan kiai sebagai rajanya. Kiai bersifat mutlak dalam kehidupan dan lingkungan pesantren sebagai sumber kekuasaan dan otoritas. Dengan demikian, dapat dikatakan bahwa penentu arah dan tujuan kebijakan pendidikan pesantren hanya bergantung pada kewenangan Kiai.

Sumber dan bentuk power kekuasaan, jika dapat ditelusuri kembali ke sejarah, dapat ditelusuri kembali ke pernyataan Machiavelli yang pertama kali dibuat pada abad ke-16. Sementara Amitai Etziomi ${ }^{6}$ membahas bahwa kekuasaan memiliki dua sumber dan bentuk, yaitu kekuasaan Posisi (Position Power) dan kekuatan pribadi (personal power).

Menurut Etziomi, perbedaan keduanya terletak pada konsep kekuasaan itu sendiri, yaitu kekuasaan itu sendiri mempunyai kemampuan untuk mempengaruhi perilaku. Kekuasaan dapat berasal dari status organisasi, pengaruh pribadi atau keduanya. Jika seseorang memiliki kemampuan untuk mempengaruhi perilaku kerja orang lain karena jabatan organisasinya, orang tersebut memiliki Position Power. Orang yang memperoleh kekuatan dari pengikut dikatakan memiliki personal power.

Kekuasaan yang terdapat dalam diri seseorang atau kelompok bersumber lantaran hal berikut ${ }^{7}$ (a) terdapat kedudukan dalam organisasi (kekuasaan jabatan). Kekuatan jabatan mengacu pada kemampuan seseorang untuk mempengaruhi dan mempengaruhi, karena orang

5 Imron Arifin, Kepemimpinan kyai: kasus Pondok Pesantren Tebuireng, 1 ed. (Malang: Kalimasahada Press, 1993), 64.

${ }^{6}$ Amitai Etzioni, The New Golden Rule: Community And Morality In A Democratic Society (New York, United State of America: Basic Books, 1998), 65.

7 Zainuddin Maliki, Sosiologi Politik: Makna Kekuasaan Dan Transformasi Politik (Yogyakarta: UGM PRESS, 2018), 64. 
tersebut mempunyai kedudukan dalam organisasi, sehingga dapat memaksakan hal-hal tertentu kepada orang lain. (b) Kepribadian seseorang (Personality Power) mengacu pada pengaruh seseorang, karena ia memiliki sifat tertentu, sehingga ia dihormati dan ditaati. (c) Tenaga ahli artinya seseorang dikenali oleh orang lain karena keahliannya dan memiliki pengaruh, sehingga orang lain menjadi tergantung padanya. (d) Ada kemungkinan hal-hal penting terjadi (Opportunity power) artinya seseorang memiliki kekuatan karena ada peluang dalam suatu hal yang penting, misalnya seseorang dapat mengakses informasi penting atau dapat mengakses apa yang dibutuhkan orang lain. (e) Kekuatan fisik mengacu pada kemampuan atau pengaruh seseorang atau kelompok dengan kemampuan fisik yang kuat, misalnya, orang yang kuat secara fisik atau kelompok dengan banyak anggota atau perlengkapan yang baik, seperti seorang prajurit. (f) Kepemilikan kekuatan ekonomi mengacu pada kekuatan orang yang memiliki sumber daya ekonomi berupa kekayaan, yang biasa disebut dengan reward power, yaitu seseorang dapat mengontrol perekonomian. (g) Memiliki lebih banyak pengetahuan (kapasitas pengetahuan) daripada yang lain, artinya pengetahuan seseorang memungkinkan orang tersebut untuk mengontrol informasi.

Robbins ${ }^{8}$ mengemukakan dalam bukunya "Organizational Behavior Essentials" bahwa kekuasaan memiliki dua sumber, yaitu: (a) Kekuatan formal, yaitu kekuasaan yang didasarkan pada status individu dalam organisasi. Kekuasaan formal dibedakan menjadi tiga jenis, yaitu ceorcive power, Reward Power dan legitimate power.

Ceorcive Power adalah kekuatan hukuman, dan pengikut mematuhinya karena takut. Manajer akan mempromosikan bawahannya karena tugasnya tidak terlalu berhasil, bahkan jika hukumannya tidak berpengaruh Berharap hukuman masih menjadi kekuatan koersif digunakan untuk memperoleh kepatuhan atau untuk memperbaiki perilaku yang tidak produktif dalam organisasi.

Reward power adalah kemampuan yang didasarkan pada kemampuan seseorang untuk memberi penghargaan kepada pengikut dan kepatuhannya kepada pengikut. Jika pengikut menganggap hadiah atau kemungkinan yang diberikan oleh seseorang sebagai tanggapan atas suatu perintah, seperti di lembaga pendidikan, kekuatan penghargaan ini digunakan untuk mendukung legitimasi.Jika kepala sekolah dapat

8 Stephen P. Robbins, David A. Decenzo, dan Mary Coulter, "Fundamentals of Management Essential Concepts and Aplications," Eighth, 8 th (Uniteted States of America: Pearson, 2013), 78.

186 JURNAL LISAN AL-HAL 
memenangkan siswa, kepala sekolah akan memberikan penghargaan Beri penghargaan kepada guru dalam bentuk Dalam kompetisi atau Olimpiade.

Legitimate Power adalah kemampuan seseorang untuk memiliki pengaruh karena statusnya. Orang dengan kekuasaan yang lebih tinggi memiliki hak untuk mengontrol orang dengan status yang lebih rendah. Secara teori, organisasi yang setara memiliki kekuatan hukum yang sama. Namun, setiap orang dengan kekuatan hukum sesuai dengan konsep otoritas Weber. Jika bawahan menganggap penggunaan kekuasaan sebagai legal, mereka akan memainkan peran penting dalam menjalankan kekuatan hukum, tetapi mereka akan patuh, tetapi budaya, kebiasaan dan sistem nilai organisasi menentukan batas-batas kekuatan hukum. Seorang direktur perusahaan yang menyarankan semua karyawan untuk memilih partai politik tertentu mungkin menemukan bahwa hanya beberapa orang yang mengikuti nasihatnya.

Authority atau otoritas merupakan hak untuk melakukan sesuatu atau memerintahkan orang lain untuk melakukan atau tidak melakukan sesuatu dengan tujuan agar misi dari lembaga tercapai dengan baik. Banyak orang memahami authority atau masyhur dalam bahasa Indonesia adalah otoritas merupakan wujud kekuasaan seseorang atas orang lain. Ketika seseorang memiliki kekuasaan (misalnya, dalam lingkup pekerjaan tertentu), maka kekuasaan adalah pasti miliknya. Baik itu kekuatan untuk mengatur, mengontrol, atau memutuskan sesuatu.

Max Weber percaya bahwa ada perbedaan antara kekuasaan dan otoritas: kekuasaan mencakup kekuatan dan paksaan, dan authority adalah bagian dari power atau kekuatan. Dengan kata lain otoritas tidak memiliki pengaruh pada kekuasaan, tetapi mencakup beberapa penilaian dalam aspek kekuasaan.

Power tanpa authority akan menjadi kekuatan illegal oleh karenanya, power harus mendapat legitimasi dari masyarakat untuk mencerminkan bahwa power berjalan dengan baik. Kekuasaan itu sendiri masih abstrak. Kekuatan haruslah disertai otoritas. Kekuasaan yang tidak sah memiliki arti yang kecil, sehingga perlu dilegalkan dan dilembagakan agar kekuasaan baru dapat diterima.

\section{Internalisasi Power and Authority dalam Pendidikan Pesantren}

Sebagai sebuah fenomena ilmiah, kepemimpinan, masyarakat, politik, budaya dan kekuasaan memiliki definisi atau ciri tertentu. Kekuasaan adalah sesuatu yang abstrak, tidak terlihat atau tidak terbaca. Dalam organisasi formal, kekuasaan diwujudkan dalam tanda-tanda hierarkis, seragam resmi, lambang, dan posisi seseorang dalam sistem 
sosial. Untuk membuat semua orang sadar akan tugas mereka, anggota polisi misalnya mengenakan seragam polisi dan tanda pangkat. Seorang kiaipun sebagai sebuah role model di kerajaan kecil yang dipimpinnya saat melaksanakan tugas kepondokan identic dengan atribut kekiaiannya seperti sarung, kopyah, tasbih, surban dan lainnya.

Wayne K. Hoy ${ }^{9}$ membuat tabel yang membandingkan Peabody, Blau dan Scott, Weber, Ezione, Francis dan Lavin dan Mintzberg Tampilan (lihat Tabel 1). Perbandingan tersebut didasarkan pada pemahaman pertama tentang hal-hal berikut: Otoritas pada dasarnya adalah bagian dari kekuasaan. Jika kekuasaan adalah kekuasaan legal, maka kekuasaan mencakup kekuasaan legal dan ilegal. Kedua, berdasarkan pemahaman ini, kekuasaan dan kewenangan mempunyai empat sumber: legalitas formal, legalitas informal, ilegalitas formal dan ilegalitas informal.

Tabel: 1 sumber-sumber kekuasaan dan otoritas

\begin{tabular}{|c|c|c|c|c|c|c|}
\hline & Peabody, & $\begin{array}{c}\text { Blau dan } \\
\text { Scott }\end{array}$ & Weber & Etzioni & $\begin{array}{c}\text { French dan } \\
\text { Raven }\end{array}$ & Mintzberg \\
\hline $\begin{array}{c}\text { Legitimate } \\
\text { formal } \\
\text { power }\end{array}$ & $\begin{array}{c}\text { Formal } \\
\text { authority }\end{array}$ & $\begin{array}{c}\text { Formal } \\
\text { authority }\end{array}$ & $\begin{array}{c}\text { Bureaucratic } \\
\text { authority }\end{array}$ & $\begin{array}{c}\text { Remunerative } \\
\text { power }\end{array}$ & $\begin{array}{c}\text { Reward } \\
\text { power and } \\
\text { legitimate } \\
\text { power }\end{array}$ & $\begin{array}{c}\text { System of } \\
\text { authority }\end{array}$ \\
\hline $\begin{array}{c}\text { Ligitimate } \\
\text { informal } \\
\text { power }\end{array}$ & $\begin{array}{c}\text { Functional } \\
\text { authority }\end{array}$ & $\begin{array}{c}\text { Informal } \\
\text { authority }\end{array}$ & $\begin{array}{c}\text { Charismatic } \\
\text { authority and } \\
\text { traditional } \\
\text { authority }\end{array}$ & $\begin{array}{c}\text { Normative } \\
\text { power }\end{array}$ & $\begin{array}{c}\text { Referent } \\
\text { power and } \\
\text { expert } \\
\text { power }\end{array}$ & $\begin{array}{c}\text { System of } \\
\text { ideology } \\
\text { and system } \\
\text { of } \\
\text { expertice }\end{array}$ \\
\hline $\begin{array}{c}\text { Illigitimate } \\
\text { formal } \\
\text { power }\end{array}$ & & & & $\begin{array}{c}\text { Coercive } \\
\text { power }\end{array}$ & $\begin{array}{c}\text { Coercive } \\
\text { power }\end{array}$ & System of \\
\hline $\begin{array}{c}\text { pligitimate } \\
\text { informal } \\
\text { power }\end{array}$ & & & & & & \\
\hline
\end{tabular}

Berdasarkan Tabel 1, sumber atau jenis kekuasaan dan kewenangan dicantumkan secara rinci yaitu: referent power, expert power, legitimate power, reward power, coercive power dan charismatic power and authority power. Kiai di Pondok Pesantren Miftahul Ulum Kalisat Jember menggunakan enam sumber atau jenis kekuasaan dan otoritas ini. Tidak ada yang secara khusus bergantung pada satu jenis atau sumber. Loyalitas di pondok pesantren ini dikonstruksi dengan mengedepankan asas norma,

${ }^{9}$ Wayne Hoy dan Cecil Miskel -, "Educational Administration: Theory, Research, and Practice" (New York, United State of America: McGraw-Hill Companies,Incorporated, t.t.), 121.

$188 \mid$ JURNAL LISAN AL-HAL 
ideology serta nilai-nilai pengabdian dan pejuang pendidikan dan bukan pada pribadi kiai. Referent power sebagaimana diinternalisasi di pondok ini demi meminimalisir perilaku ketergantungan pada sosok kiai dan menghindari pengambilan kebijakan yang berasaskan perasaan. Demi mendukung performance job dalam proses pelaksanaan manajerial, kiai di pondok ini menggunakan instrument musyawarah mufakat dengan demikian diharapkan otoritas yang dibangun dapat menyebar pada pimpinan dibawahnya yang dipercaya. Kekuatan pada referent power bukan saja diintimidasi oleh seorang kiai tapi juga dapat dimiliki dan terinternalisasi dalam sebuah kelompok, bahkan bagian dari sebuah kelompok dapat memilikinya. Bagi Hoy referent power tidak hanya terkait dengan pemegang kekuasaan resmi suatu organisasi, pada kenyataannya, banyak orang yang sangat baik membangun kehormatan, kepercayaan, dan kesetiaan serta loyalitas di antara rekan kerja. Upaya dan perilaku ini sangat mirip dengan pengembangan kemampuan referent power.

Expert power merupakan kemampuan manajer untuk mempengaruhi perilaku bawahan berdasarkan keterampilan dan keahlian khusus ${ }^{10}$. Dalam konteks lembaga seperti pondok pesantren, bawahan terpengaruh karena mereka percaya bahwa informasi dan keahlian yang dimiliki oleh seorang kiai sangat relevan dan dapat membantu, dan mereka menyadari bahwa mereka tidak memiliki informasi sebagaimana keahlian yang dimiliki seorang kiai. Seperti hak referensi, sebagaimana referent power, expert power dalam hal ini juga juga merupakan karakteristik pribadi dan tidak tergantung pada otoritas dari kekuasaan maupun jabatan seseorang dan dapat dimiliki oleh siapa saja yang bukan seorang manajer atau administrator dari sebuah lembaga. Agar expert power terinternalisasi dengan baik maka kiai dianggap perlu untuk memperkenalkan pengetahuannya dalam hal administrasi maupun keahlian lain yang dimilikinya kepada bawahan sehingga bawahan dapat merasa berhasil dalam melakukan keterampilan sebagaimana dilakukan oleh seorang kiai. Seorang kiai dapat menampilkan ilmunya secara meyakinkan dan dapat menjaga reputasi pengetahuannya, dan perilaku kiai menunjukan sisi expert saat menunjukkan keahlian. Mengenali kepentingan bawahan.

Kiai sebagai manajer di pondok pesantren Miftahul Ulum Kalisat Jember benar-benar mengetahui kemampuan para pendukungnya dalam

10 Wayne Hoy dan Page Smith, "Influence: A key to successful leadership," International Journal of Educational Management 21 (27 Februari 2007): 128, https://doi.org/10.1108/09513540710729944. 
proses manajerial dan hal ini menjadi kunci utama dalam internalisasi expert power. ada beberapa alasan mengapa sebagai manajer kiai di pondok ini mengetahui keunggulan dari para bawahannya dalam mengelola pondok. Alasan utamanya yakni para bawahannya itu merupakan kerabat dan kolega yang masih dalam satu rumpun keturunan. Kiai di pondok ini mengetahui sanad keilmuan para bawahannya dari masa kecil, rekam keilmuan dari masa pondok hingga keahlian selama berkembang bersama pondok.

Legitimate power merupakan kemampuan seorang manajer untuk mempengaruhi perilaku orang lain dengan simple karena adanya jabatan formal. Tipe ini senantiasa bekerjasama dengan para bawahan lantaran seorang manajer memiliki hak memberikan tugas dan petunjuk pekerjaan kepada mereka yang punya kewajiban terhadap lembaga untuk dilaksanakan. Setiap manajer diharapkan dapat memberikan konstribusinya dalam mengambil kebijakan dan mempertanggungjawabkannya kepada lembaga. Yulk ${ }^{11}$ memberikan pandangannya agar tipe ini dapat berjalan dengan baik antaranya kebijakan yang berbasis perintah dan tuntutan lembaga setidaknya dapat diterima bawahan dan transparan sehingga kredibelitas dan pertanggungjawabannya dapat dipenuhi. Penjelasan mengapa kebijakan tersebut diambil penting untuk diketahui bawahan, pemegang kebijakan perlu peka terhadap kepentingan bawahan. Hal ini diinternalisasi di pondok pesantren Miftahul Ulum dengan baik lantaran kebijakan yang diberlakukan oleh kiai mengusung tipe transparansi seperti halnya dalam proses kedatangan para santri saat telah usai dari liburan panjang di akhir tahun. Kiai di pondok ini mengambil kebijakan dengan memeriksa semua santri dari aspek kesehatan hingga barang bawaannya saat kembali ke pondok dan hal ini telah diketahui oleh bawahannya dengan transparan dan sesuai dengan kebutuhan bawahan pelaksana kegiatan cek kesehatan karena adanya pademi covid 19.

Reward power merupakan keahlian yang dimiliki oleh seorang manajer guna membuat perubahan perilaku anggota dengan cara memberikan perhatian pada perilaku anggota dengan cara menyenangkan. Reward power sebagaimana diinternalisasi oleh kiai di pondok pesantren Miftahul Ulum ini ditunjukan saat acara haflul ikhtitam akhirissanah dan penghargaan yang tidak bersifat materi seperti diberikan keleluasaan dalam mengelola beberapa bagian dalam pengembangan pondok. Penghargaan diberikan secara merata kepada semua orang yang

11 Yukl, Leadership in Organizations, 54.

$190 \mid$ JURNAL LISAN AL-HAL 
menunjukkan etika profesional yang baik. Temuan menarik lainnya adalah bahwa reward tidak dianggap sebagai bagian dari motivasi langsung etika profesi, melainkan untuk menjaga hubungan interpersonal antara kiai, guru dan santri. Reward yang diberikan oleh pimpinan dalam hal ini tidak berasal dari biaya yang dipungut dari sumber pemasukan dari santri melainkan dari kiai langsung sehingga tidak berdampak pada kas pondok secara langsung ${ }^{12}$ pembiayaan untuk memberikan reward dihadirkan dalam rangka penghargaan langsung dari seorang manajer saat merefleksikan kinerja dari bawahan. Pemberian reward yang dibiayai secara personal tersebut dalam rangka menunjukan perhatian seorang kiai dalam sistem manajerialnya demi kepentingan lembaga. Nah hal yang demikian tersebut mendapat respon positif dari asatidz sebagai nilai-nilai karakter dari seorang kiai yang zuhud dan penuh dengan nilai religiusitas. ${ }^{13}$

Sumber berikutnya yakni coercive power yaitu manajer mempengaruhi kemampuan bawahan dengan menghukum perilaku bawahan yang tidak menyenangkan. Menurutnya, coercive power bergantung pada beratnya hukuman. Untuk menghindari perlawanan saat menggunakan coercive power, poin-poin berikut harus diperhatikan, Pertama, bawahan harus memahami sepenuhnya aturan dan metode penerapan sanksi. Kedua, disiplin harus diawasi dengan baik, konsisten dan jujur. Ketiga, administrator harus menjaga kredibilitas dan tetap tenang. Keempat, administrator harus mencegah permusuhan. Kelima, gunakan hukuman yang jelas dan terukur. Keenam, hilangkan dampak negative. Pondok Miftahul Ulum menggunakan kekuatan koersif dalam hal-hal yang terkait dengan pelanggaran hukum dan tidak menggunakannya untuk semua upaya penegakan disiplin. Semua asatidz mengetahui dengan benar bagaimana disiplin dan peraturan melekat dalam tradisi pondok pesantren.

\section{Simpulan}

Kekuasaan (power) adalah kesempatan amanah bagi individu atau sekelompok orang untuk menyadarkan individu atau kelompok lain untuk menerima kemauan yang mereka inginkan baik dengan cara memaksa ataupun legitimasi kesadaran dari individu lainnya. Authority atau otoritas

12 Badrut Tamam, "Reorientasi Pendanaan Pendidikan dalam Membangun Mutu Sekolah," Misykat Al-Anwar 29, no. 2 (2018): 45, https://doi.org/10.31904/ma.v29i2.2855.

${ }^{13}$ Badrut Tamam dan Akhmad Muadin, "IMPLEMENTASI EDUPREUNEURSHIP DALAM PEMBENTUKAN KARAKTER SEKOLAH UNGGUL," Ulumuna: Jurnal Studi Keislaman 5, no. 1 (10 Juni 2019): 76, https://doi.org/10.36420/ju.v5i1.3521. 
yakni hak untuk melakukan sesuatu atau memerintahkan orang lain untuk melakukan atau tidak melakukan sesuatu dengan tujuan agar misi dari lembaga tercapai dengan baik.

Tipe atau sumber power and authority yang digunakan oleh kiai pondok pesantren Miftahul Ulum yakni, referent power, reward power, coercive power, legitimate power dan expert power. Ke lima tipe dan sumber kekuasaan dan otoritas tersebut menjadi penguat dalam peran manajerial seorang kiai dan bagi pengembangan pondok pesantren.

\section{DAFTAR PUSTAKA}

Arifin, Imron. Kepemimpinan kyai: kasus Pondok Pesantren Tebuireng. 1 ed. Malang: Kalimasahada Press, 1993.

Etzioni, Amitai. The New Golden Rule: Community And Morality In A Democratic Society. New York, United State of America: Basic Books, 1998.

Griffin, Ricky W., dan Gregory Moorhead. "Organizational Behavior ,.” Boston, Massachusetts, Amerika: Cengage Learning, 2011.

Hersey, Paul, Kenneth H. Blanchard, dan Dewey E. Johnson. Management of Organizational Behavior: Leading Human Resources. 11 ed. London; Britania Raya: Pearson, 2013.

Hoy, Wayne, dan Cecil Miskel -. "Educational Administration: Theory, Research, and Practice." New York, United State of America: McGrawHill Companies,Incorporated, t.t.

Hoy, Wayne, dan Page Smith. "Influence: A key to successful leadership." International Journal of Educational Management 21 (27 Februari 2007): 158-67. https://doi.org/10.1108/09513540710729944.

Maliki, Zainuddin. Sosiologi Politik: Makna Kekuasaan Dan Transformasi Politik. Yogyakarta: UGM PRESS, 2018.

P. Robbins, Stephen, David A. Decenzo, dan Mary Coulter. "Fundamentals of Management Essential Concepts and Aplications," Eighth. 8 th. Uniteted States of America: Pearson, 2013.

Tamam, Badrut. "Reorientasi Pendanaan Pendidikan dalam Membangun Mutu Sekolah." Misykat Al-Anwar 29, no. 2 (2018): 257189. https://doi.org/10.31904/ma.v29i2.2855.

Tamam, Badrut, dan Akhmad Muadin. "IMPLEMENTASI EDUPREUNEURSHIP DALAM PEMBENTUKAN KARAKTER SEKOLAH UNGGUL." Ulumuna: Jurnal Studi Keislaman 5, no. 1 (10 Juni 2019): 13-21. https://doi.org/10.36420/ju.v5i1.3521.

$192 \mid$ JURNAL LISAN AL-HAL 
Umanailo, M Chairul Basrun. MAX WEBER. Namlea: FAM PUBLISHING, 2019. https://doi.org/10.31219/osf.io/ep7bn.

Yukl, Gary A. Leadership in Organizations. Upper Saddle River, New Jersey, Amerika: Prentice Hall, 1998. 
"Nilai Power And Authority"

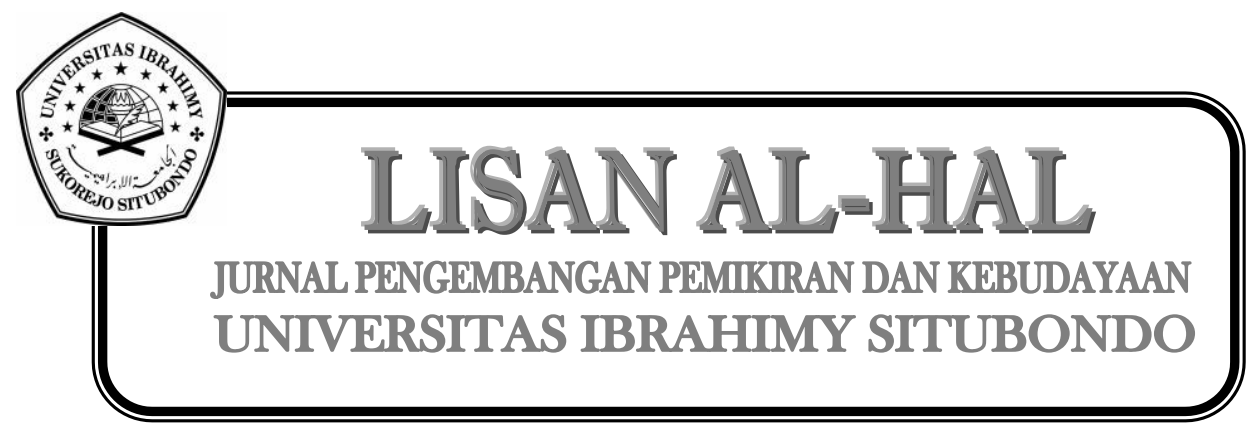

194 JURNAL LISAN AL-HAL 